Original Research Paper

\title{
Demplot Penerapan Teknik Reproduksi Terkontrol untuk Promosi Kinerja Perbibitan Kambing Potong di Kecamatan Praya Barat Daya Kabupaten Lombok Tengah
}

\author{
Lalu Wira Pribadi ${ }^{1 *}$, Rr. Agustien Suhardiani ${ }^{1}$, Tahyah Hidjaz ${ }^{1}$, Happy Poerwoto ${ }^{1}$, M. Ashari ${ }^{1}$, dan Rina \\ Andriati $^{1}$ \\ ${ }^{1}$ Laboratorium Ternak Potong dan Kerja Fakultas Peternakan Universitas Mataram, Mataram, Indonesia;
}

https://doi.org/10.29303/jpmpi.v3i2.955

Sitasi: Pribadi, L. W., Suhardiani, Rr. A., Hidjaz, T., Poerwanto, H., Ashari, M \& Andrianti, R. (2021). Demplot Penerapan Teknik Reproduksi Terkontrol untuk Promosi Kinerja Perbibitan Kambing Potong di Kecamatan Praya Barat Daya Kabupaten Lombok Tengah. Jurnal Pengabdian Magister Pendidikan IPA, 4(3)

\author{
Article history \\ Received: 28 Agustus 2021 \\ Revised: 11 September 2021 \\ Accepted: 13 September 2021 \\ *Corresponding Author: Lalu \\ Wira Pribadi, Laboratorium \\ Ternak Potong dan Kerja \\ Fakultas Peternakan \\ Universitas Mataram, Mataram, \\ Indonesia. Email: \\ wirapribadi19@gmail.com
}

Abstract: Suatu kegiatan pengabdian kepada masyarakat dengan tujuan pokok untuk mengembangkan system produksi kambing perbibitan dengan penerapan Teknik Reproduksi Terkontrol di Kabupaten Lombok Tengah, NTB, dilaksanakan dalam bentuk penyuluhan dengan metode demplot, pelatihan, dan diseminasi Ipteks melalui penyebaran leaflet kepada peternak. Kegiatan berlokasi di Desa Darek Kecamatan Praya Barat Daya, dengan sasaran strategis adalah para peternak pada dua kelompok peternakan kambing perbibitan, dari kedua kelompok diambil 20 peternak sebagai sasaran langsung pembinaan. Demplot dilakukan menggunakan 20 ekor kambing induk Peranakan Etawa(PE) umur 2,0-2,5 tahun dengan BCS rata-rata 4. Sistem produksi kambing perbibitan dengan penerapan Teknik Reproduksi Terkontrol didemonstrasikan pada kedua kelompok mitra mulai dari pemilihan kambing-kambing induk, sinkronisasi birahi dengan introduksi Prostaglandin F2 $\alpha$ intravaginal menggunakan hand made spong, penerapan teknik flushing dengan pemberian pakan konsentrat comfeed, pengamatan tanda-tanda birahi kambing-kambing induk pasca sinkronisasi, pelaksanaan perkawinan kambing-kambing induk secara IB menggunakan semen beku pejantan Boer, deteksi kebuntingan menggunakan non return rate, pemeliharaan kebuntingan dengan pemberian pakan suplemen dan vitamin, penanganan parturisi, penanganan cempe neonatal dan pengukuran berat lahir hingga penyapihan dan pengukuran berat sapih, promosi pertumbuhan cempe lepas sapih dengan suplementasi probiotik EM4, penilaian performa kambing bibit dengan pengukuran langsung berat badan dan dimensi vital kambing. Capaian tujuan dan manfaat kegiatan yang dievaluasi dengan teknik survey menggunakan quisioner dan pengukuran langsung performa reproduksi kambing induk dan performa cempe yang dihasilkan di dalam demplot menunjukkan, semua peternak dari kedua kelompok mitra/sasaran telah memahami dengan baik materi Ipteks yang diberikan penyuluh dan dipandang telah mampu mengembangkan system produksi kambing perbibitan dengan penerapan teknik reproduksi terkontrol. Penerapan teknik reproduksi terkontrol dalam usaha ternak kambing perbibitan sangat bermanfaat dalam meningkatkan efisiensi reproduksi kambing induk dan produktivitas perbibitan yang diusahakan.

Keywords: kambing potong, perbibitan, teknik reproduksi terkontrol, demplot, efisiensi reproduksi, produktivitas kambing bibit 


\section{Pendahuluan}

Ternak kambing di Indonesia memiliki potensi yang cukup penting karena mempunyai kegunaan yang bermacam-macam dan penyebarannya cukup luas serta mampu menghasilkan uang kes jangka menengah (bulanan) bagi peternak. Sifatnya yang cepat berkembang biak memposisikan ternak kambing pada urutan kedua dari ternak yang mampu mensuplai kebutuhan daging nasional setelah sapi. Demikian pula, beberapa jenis kambing lokal (seperti kambing PE dan kambing Batang) diketahui mampu memproduksi susu melebihi kebutuhan untuk anak-anaknya, hal ini memberi harapan adanya kontribusi ternak kambing dalam upaya meningkatkan konsumsi susu masyarakat.

Usaha produksi kambing di berbagai daerah, sebagian besar merupakan usaha perbibitan disamping sebagian lainnya memproduksi kambing potong untuk dipasarkan sebagai hewan qurban, aqiqah, dan penyediaan kebutuhan konsumsi. Dalam budidaya ternak kambing perbibitan, berdasarkan hasil investigasi pada kelompokkelompok usahatani kambing di Kabupaten Lombok Tengah Provinsi Nusa Tenggara Barat (Pribadi dan Rodiah, 2011), perternak memelihara induk-induk kambing muda umur 1-3 tahun yang kemudian dikawinkan dengan pejantan milik sendiri atau milik peternak lain, guna menghasilkan anak-anak kambing (cempe) yang selanjutnya dibesarkan beberapa bulan hingga menjadi kambing-kambing bibit atau bakalan yang siap dipasarkan.

Jenis kambing induk yang banyak dipelihara kalangan peternak kambing di Lombok Tengah untuk produksi perbibitan adalah jenis Peranakan Etawa (PE). Selain itu, pada pertengahan 2007 lalu telah diintroduksi induk kambing Batang sebanyak 50 ekor dan 5 ekor pejantan Kambing Boer melalui program Iptekda LIPI di desa Darek Kecamatan Praya Barat Daya (Zainuri $d k k ., 2008$ ). Keberadaan induk-induk kambing Batang dan pejantan Boer tersebut di desa Darek merupakan potensi sumberdaya genetic yang sangat penting dalam upaya meningkatkan produktivitas kambing rakyat kearah grade kambing potong unggul di Lombok Tengah.

Permasalahan pokok yang dihadapi, yaitu belum adanya usaha ternak kambing perbibitan yang menghasilkan breeding stock yang sustainable, sementara produktivitas dan efisiensi produksi perbibitan kambing yang dijalankan oleh kelompok-kelompok peternak yang ada masih tergolong rendah, karena usaha tersebut menunjukkan pola yang masih tradisional. Adapun permasalahan umum yang dihadapi, adalah kurangnya pengetahuan dan keterampilan teknis maupun manajemen para anggota kelompok dalam hal usaha perbibitan ternak yang efektif, efisien, dan berkelanjutan.

Jika diidentifikasi, maka terdapat beberapa permasalahan khusus terkait dengan performa ternak kambing perbibitan pada umumnya, sebagai berikut: 1)kid crop (jumlah anak kambing yang dihasilkan) masih rendah, karena teridentifikasi masih rendahnya angka kelahiran kembar pada induk kambing yang diusahakan, 2)kidding interval (interval kelahiran anak) yang panjang menyebabkan menjadi rendahnya efisiensi reproduksi ternak, 3)mortalitas neonatal (kematian anak baru lahir) sering terjadi akibat kurang baiknya penanganan kondisi neonatal, 4)laju pertumbuhan kambing lepas sapih tergolong rendah, sehingga lama waktu untuk pemeliharaan anak kambing hingga dicapainya performa standar untuk kambing bibit/bakalan menjadi relatip panjang, dan kualitas performa kambing bibit/bakalan yang dihasilkan kurang memadai, 5)minimnya upaya recording dalam pelaksanaan usaha produksi, sehingga proses produksi menjadi kurang terkontrol dan tidak efisien.

Berdasarkan permasalahan tersebut, maka dilakukan kegiatan pengabdian kepada masyarakat di kalangan kelompok peternak kambing di Kecamatan Praya Barat Daya Kabupaten Lombok Tengah, NTB melalui pelaksanaan demplot peneraapan teknik reproduksi terkontrol. Tujuan pokoknya adalah untuk meningkatkatkan pengetahuan dan keterampilan peternak kambing perbibitan, meningkatkan grade (promosi) performa perbibitan kambing potong dan mengembangkan usaha perbibitan kambing potong unggul berbasis Ipteks di Lombok Tengah.

\section{Metode}

\section{Metode Pendekatan}

Kegiatan dilaksanakan melalui pendekatan transfer Ipteks kepada kelompok mitra. Metode pendekatan yang digunakan adalah Metode Demonstrasi Plot (Demplot) melibatkan para 
peternak anggota kelompok mitra, disertai pendampingan secara langsung dan penyelenggaraan pelatihan teknis untuk para anggota kelompok mitra.

Demplot dilaksanakan dalam bentuk praktek usaha perbibitan kambing komposit dengan penerapan teknik "Reproduksi Terkontrol" pada Kelompok Usaha Perbibitan Kambing "Kembang Turi" di Desa Darek. Teknik tersebut diterapkan pada 20 ekor kambing induk PE milik anggota kelompok yang dipilih secara acak dari induk-induk yang melahirkan 1-2 bulan sebelumnya. Jumlah peternak yang dilibatkan dalam praktek ini adalah sebanyak 20 orang. Pelaksanaan demplot berlangsung selama 7 bulan, dengan rangkaian kegiatan terdiri atas: pemilihan induk-induk kambing, penerapan teknik flushing, sinkronisasi birahi, deteksi birahi, perkawinan induk-induk birahi, pemeliharaan kebuntingan hingga kelahiran anak, penanganan neonatal, pemeliharaan anak kambing hingga penyapihan, penyapihan anak-anak kambing, pemeliharaan anak-anak kambing lepas sapih, penerapan teknik promosi pertumbuhan, penilaian performa kambing bibit/bakalan yang dihasilkan.

Pendampingan bagi para peternak diimplementasikan dengan melibatkan para peternak secara langsung dalam seluruh rangkaian kegiatan demplot. Dengan demikian, proses pendampingan ini berlangsung selama pelaksanaan demplot.

Adapun pelatihan teknis untuk para peternak dilaksanakan sebelum memulai pelaksanaan demplot. Pelatihan dilaksanakan selama 2 hari, dengan jumlah peserta 30 orang yang terdiri atas 5 orang pengurus kelompok, 20 orang peternak anggota kelompok, dan 5 orang anggota masyarakat setempat. Metode pelaksanaannya meliputi ceramah/diskusi, praktek (peragaan), dan pembagian leaflet materi pelatihan.

\section{Pelaksanaan Kegiatan}

Beberapa kegiatan yang dilaksanakan berkaitan dengan langkah-langkah solusi atas permasalahan yang ditangani, dirincikan sebagai berikut:

1) Penentuan khalayak sasaran strategis, yaitu semua peternak kambing yang terhimpun dalam Kelompok Usaha Ternak Kambing Perbibitan "Kembang Turi" dan Kelompok Peternak Kambing "Tunas Paice" di Desa
Darek Kecamatan Praya Barat Daya Kabupaten Lombok Tengah Propinsi NTB, yang berjumlah 52 kk peternak; sebagai sasaran langsung/strategis dipilih sebanyak 18 peternak yang memiliki kambing $\mathrm{PE}$ induk dengan status reproduksi 1 bulan ( \pm 30 hari) post partum pada 3 lokasi strategis di Desa darek,

2) Pelatihan teknis bagi peternak sasaran, dimaksudkan untuk memberikan bekal keterampilan teknis kepada peternak agar mampu mengikuti prosesi kegiatan secara seksama dan mampu memperbaiki kinerja usahanya; pelatihan dilaksanakan selama 2 hari, dengan jumlah peserta 30 orang yang terdiri atas 5 orang pengurus kelompok, 20 orang peternak anggota kelompok, dan 5 orang anggota masyarakat setempat, metode pelaksanaannya meliputi ceramah/diskusi, praktek (peragaan), dan pemberian leaflet materi pelatihan,

3) Pelaksanaan demplot dan pendampingan; demplot dilaksanakan dalam bentuk praktek usaha perbibitan kambing komposit dengan penerapan Teknik "Reproduksi Terkontrol" pada 2 lokasi strategis dalam wilayah usaha peternakan Kelompok Usaha Perbibitan Kambing "Kembang Turi" di Desa Darek, diterapkan pada 20 ekor induk kambing Komposit milik anggota kelompok yang dipilih secara acak dari induk-induk yang melahirkan satu bulan sebelumnya. Jumlah peternak yang dilibatkan dalam praktek ini adalah sebanyak 20 orang. Pelaksanaan demplot berlangsung selama 7 bulan, dengan rangkaian kegiatan terdiri atas:

(1) Pemilihan kambing-kambing induk, sesuai kriteria Zaenuri et al (2008) untuk dijadikan obyek demplot,

(2) Penempatan kambing-kambing induk pilihan pada kandang-kandang individu

(3) Penerapan teknik flushing, sesuai petunjuk Blakely dan Bade (1991) yaitu pemberian pakan biji2an atau bahan pakan berprotein tinggi seperti pakan konsentrat komersial (Comfeed) kepada induk-induk kambing pilihan selama 20 hari sebelum induk-induk kambing dikawinkan, dimaksudkan untuk merangsang produksi sel telur pada induk kambing dan meningkatkan jumlah sel telur yang dapat dilepaskan dari ovarium untuk dibuahi oleh sperma pada waktu induk 
kambing dikawinkan . Teknik ini untuk memacu terjadinya kelahiran kembar lebih dari 2 ekor setiap kelahiran dari seekor induk

(4) Sinkronisasi birahi kambing-kambing induk demplot, dimaksudkan untuk menyerentakkan siklus birahi induk-induk kambing sehingga dapat dikawinkan secara serentak pada waktu yang relatip sama dan tepat. Sinkronisasi birahi dilakukan dengan teknik introduksi Prostaglandin F2 $\alpha$ intravaginal menggunakan hand made sponk yang dibiarkan selama 14 hari di dalam rongga vagina

(5) Deteksi birahi kambing-kambing induk di dalam demplot, dilakukan dengan terlebih dahulu mengeluarkan sponk dari vagina setelah 14 hari, dan mengamati timbulnya gejala birahi pada 48 jam kemudian

(6) Perkawinan kambing-kambing induk, dilakukan dengan IB dan perkawinan alami secara crossing menggunakan pejantan kambing Boer cross, pada saat kambingkambing induk menunjukkan tanda-tanda birahi

(7) Pemeliharaan kebuntingan hingga kelahiran anak, dalam hal ini, induk-induk kambing dipelihara dengan pemberian pakan basal ditambah suplemen dedak padi dan mineral

(8) Penanganan anak neonatal, pemeliharaan anak kambing hingga penyapihan, penyapihan anak-anak kambing,

(9) Pemeliharaan anak-anak kambing lepas sapih dan penerapan teknik promosi pertumbuhan dengan suplementasi probiotik EM4 dalam ransum sebagai agen promosi pertumbuhan

(10)Penilaian performa kambing bibit/bakalan yang dihasilkan, dilakukan dengan menimbang berat badan dan mengukur dimensi-dimensi vital kambing

Adapun pendampingan bagi para peternak diimplementasikan dengan melibatkan para peternak secara langsung dalam seluruh rangkaian kegiatan demplot. Dengan demikian, proses pendampingan ini berlangsung selama pelaksanaan demplot.

4) Pelaksanaan recording, dalam hal ini, dirancang suatu format sistem recording sebagai alat kontrol terhadap pelaksanaan semua proses produksi dan perkembangan yang terjadi
5) Monitoring dan evaluasi, meliputi semua rangkaian kegiatan terhadap perkembangan yang terjadi dan hasil yang dicapai. Monitoring dilakukan secara terjadwal, dengan mencermati setiap perkembangan yang terjadi selama pelaksanaan demplot perbibitan. Adapun pelaksanaan evaluasi, dalam hal ini, dilakukan evaluasi kelayakan teknis Ipteks yang diterapkan, evaluasi kelayakan ekonomis usaha perbibitan yang dikembangkan, dan evaluasi respon khalayak (peternak) mitra.

\section{Partisipasi Mitra dalam Pelaksanaan Kegiatan}

Kelompok Peternak Kambing "Kembang Turi" dan "Tunas Paice" Desa Darek sebagai mitra dalam kegiatan ini memberikan partisipasi berupa : 1)Penyediaan induk-induk kambing untuk kebutuhan pelaksanaan demplot, beserta kandang dan perlengkapannya, 2)Penyediaan hijauan bahan pakan ternak secara rutin sebagai pakan dasar induk-induk kambing demplot selama demplot berlangsung, 3)Memelihara dan mengawasi kambing-kambing demplot sebagaimana mestinya, 4)Mengamati tanda-tanda birahi, kebuntingan, tanda akan melahirkan, dan perkembangan lainnya pada induk-induk kambing demplot, dan memberi informasi secepatnya kepada Tim Pelaksana Kegiatan, 5)Melaksanakan recording sesuai format yang telah dirancang, 6)Membantu penanganan ternak setiap kali diperlukan, untuk memperlancar pelaksanaan penerapan Ipteks dan pengukuran performa ternak, 7)Para peternak peserta demplot berpartisipasi aktip mempraktekkan langsung teknik-teknik yang diterapkan dalam pelaksanaan demplot dengan bimbingan Tim Pelaksana Kegiatan

\section{Hasil dan Pembahasan}

\section{Pencapaian Tujuan}

Pencapaian tujuan kegiatan penerapan Teknik Reproduksi Terkontrol untuk promosi kinerja perbibitan kambing potong rakyat pada Kelompok Peternak "Kembang Turi" dan "Tunas Paice" di desa Darek Kecamatan Praya Barat Daya Kabupaten Lombok Tengah, dapat dilihat dari hasil evaluasi yang menunjukkan, semua peternak sasaran kegiatan (100\%) menunjukkan respon positif terhadap semua rangkaian Ipteks yang diterapkan, dalam hal ini, $78 \%$ peserta telah memahami dengan baik pengetahuan praktis yang 
disampaikan penyuluh, dan $22 \%$ sisanya tampak hanya memahami bagian materi yang didemonstrasikan penyuluh saja. Dengan demikian, dapat dikatakan bahwa tujuan umum kegiatan ini untuk meningkatkan pengetahuan dan keterampilan peternak mengenai teknik dan manajemen reproduksi terkontrol untuk produksi kambing perbibitan yang efektip dan efisien, telah tercapai dengan baik.

Kegiatan pengabdian kepada masyarakat ini, juga telah dapat mengatasi permasalahanpermasalahan khusus yang dihadapi peternak dalam usaha kambing perbibitan. Adapun hasil yang dicapai, adalah:

1) Diperoleh peningkatan kelahiran kembar-3 (55\%) dan kembar-4 (15\%), sehingga kid crop meningkat dari 32 menjadi 57 ekor untuk 20 ekor induk, sehingga setiap induk dapat beranak rata-rata 2,85 (= 3 ekor) dalam 1 kali beranak. Angka litter size rata-rata 3 ekor per kelahiran ini lebih tinggi dibanding litter size kambing PE menurut Devendra dan Burns (1994) sebesar 1,5 per kelahiran, juga lebih tinggi dibanding litter size kambing silangan Boer x PE yang dilaporkan Kaunang et al (2013) sebesar rata-rata 1,8. Hal ini menunjukkan, teknik flushing dengan pakan konsentrat kwalitas tinggi (comfeed) yang diterapkan dalam demplot ini sangat efektif dalam memacu kinerja sifat prolific kambingkambing induk dalam demplot

2)

idding interval (interval beranak) dapat diperpendek dari rata-rata 225 menjadi rata-rata 177 hari. Dengan demikian, kambing-kambing induk dalam demplot ini dapat melahirkan 2 kali dalam setahun. Sehubungan setiap kambing induk dalam demplot ini mampu melahirkan 3 ekor cempe dalam satu kelahiran (lihat hasil yang dicapai poin1), maka berarti setiap induk dapat menghasilkan 6 ekor cempe dalam setahun. Angka capaian ini lebih tinggi dibanding jumlah cempe yang mampu dihasilkan kambing induk Silangan Boer $\mathrm{x}$ Kacang berkisar 5-11 ekor dalam 2 tahun, sesuai laporan Nurgiatiningsih (2016)

3) Terjadi kelahiran serentak dalam waktu 22 hari, sehingga penanganan neonatal lebih mudah dan terarah. Kelahiran serentak anak-anak kambing (cempe) merupakan hasil penerapan perkawinan serentak kambing-kambing induk dalam waktu 20 hari, sebagai tindak lanjut dari terjadinya birahi serentak dari hasil penerapan teknik sinkronisasi birahi pada kambingkambing induk di dalam demplot.

4) Kejadian mortalitas neonatal (kematian anak yang baru lahir) dapat diminimalisir, ditemukan hanya $1(1,9 \%)$ kasus yaitu pada cempe yang lahir kembar 4. Angka ini jauh lebih rendah dibanding angka mortalitas neonatal kambing Silangan Boer x PE rata-rata 10,7\% sebagaimana dilaporkan Kaunang et al (2013), juga lebih rendah dibanding mortalitas prasapih kambing Silangan Boer $\mathrm{x}$ Kacang menurut laporan Nurgiatiningsih (2016) berkisar 10$15 \%$. Sebagai gambaran mengenai kondisi fisiologis cempe neonatal atau dalam fase prasapih, Wodzica-Tomaszewska et al (1993) menjelaskan, pada kambing fase prasapih dapat dikatakan merupakan periode kritis, karena pada fase pra sapih, anak belum mampu secara aktif membentuk antibodi untuk melindungi dirinya. Satu-satunya jalan ialah secara pasif dan kolostrum. Menurut pengalaman dan hasil dari penelitian-penelitian, ternyata memang pada periode lahir sampai sapih merupakan saat dengan angka kematian anak dan induk yang tertinggi.

5) Berat badan (lahir, sapih, maupun lepas sapih) cempe yang dihasilkan, demikian juga laju pertumbuhan cempe pra maupun lepas sapih meningkat sehingga lama waktu untuk pemঝiharaan anak kambing hingga dicapainya performa standar untuk kambing bibit/bakalan menjadi lebih singkat, dan kualitas performa kambing bibit/bakalan yang dihasilkan cukup memadai. Demikian juga berdasarkan performa yang diukur secara langsung dari parameter panjang badan, tinggi badan, dan lingkar dada cempe saat baru lahir, fase pra sapih maupun lepas sapih, dapat dinyatakan bahwa cempe yang dihasilkan oleh kambing-kambing induk dalam demplot ini memiliki kwalitas performa yang lebih tinggi disbanding cempe dari kambing-kambing induk non demplot.

6) Pelaksanaan recording dalam pelaksanaan usaha produksi berjalan cukup baik, sehingga proses produksi menjadi terkontrol dan efisien.

\section{Pencapaian Manfaat}


Ipteks yang diterapkan, sebagaimana hasil evaluasi yang dilakukan, tampak sangat membantu para peternak dalam mengatasi permasalahan inefisiensi usaha kambing perbibitan yang dihadapi selama ini, karena penerapan inovasi tersebut ternyata dapat meningkatkan efisiensi reproduksi dan kualitas produksi kambing bibit yang dihasilkan. Dengan peningkatan kuantitas dan kualitas kambing bibit yang dicapai, para peternak dapat meningkat pendapatannya hingga sekitar 47 $63 \%$ terhadap pendapatan dari usaha ternak kambing perbibitan yang dijalankan sebelumnya.

Disamping manfaat yang diperoleh langsung oleh para peternak, kegiatan ini juga tampak bermanfaat terhadap berkembangnya sistem perbibitan kambing dengan penerapan Reproduksi Terkontrol di kalangan kelompok usaha ternak kambing perbibitan setempat. Perkembangan ini secara tidak langsung akan memberi manfaat pula dalam membantu upaya perbaikan tatalaksana usaha ternak kambing perbibitan berbasis Ipteks yang tengah digalakkan pemerintah, dalam rangka swasembada nasional protein hewani.

\section{Faktor Pendorong dan Penghambat}

Beberapa faktor yang menjadi pendorong terlaksananya kegiatan Pengabdian kepada Masyarakat ini, adalah: 1)Program pemerintah dalam bidang peternakan, yang, salah satu diantaranya adalah Program Swaseembada Protein Hewani (PSPH), yang ditargetkan tercapai pada 2025, 2)Peran aparat pemerintah setempat, terutama kepala desa beserta perangkatnya, yang sangat antusias dalam mendukung lancarnya pelaksanaan kegiatan ini, 3)Dukungan masyarakat, terutama para tokoh dan pemuka masyarakat setempat, berupa berbagai masukan sebagai bahan kajian dan pertimbangan bagi tim penyuluh, dukungan tenaga dan tempat, juga berupa peran serta dalam pengerahan massa, 4)Adanya kesadaran para peternak terhadap pentingnya ilmu pengetahuan dan teknologi dalam rangka meningkatkan keterampilan dan hasil beternak mereka. Hal ini cukup membantu dalam menghasdirkan mereka untuk mengikuti kegiatan ini, dan yang terpenting adalah motivasi mereka untuk mengikuti kegiatan ini didasari oleh kebutuhan mereka terhadap pengetahuan dan teknologi, 5)Adanya kelembagaan petani/peternak, antara lain kelompok-kelompok peternak kambing, keberadaannya sangat potensial sebagai media penyebaran informasi inovatif dalam masyarakat. Kelembagaan yang ada, juga dapat menjadi sasaran strategis kegiatan pengabdian kepada masyarakat, 6)Adanya balai atau berugaq di sekitar kandang lokasi kegiatan, dapat menjadi tempat berkumpul para peternak untuk membahas/mengembangkan informasi inovatif yang disuluhkan.

Adapun beberapa faktor yang dipandang sebagai penghambat kelancaran pelaksanaan kegiatan pengabdian pada masyarakat ini, adalah : 1)Rendahnya tingkat pendidikan rata-rata peternak peserta penyuluhan yang menjadi sasaran langsung kegiatan. Sebagian besar petani/peternak tersebut $(56 \%)$ hanya berpendidikan SD bahkan terdapat $8 \%$ lainnya tidak berpendidikan dan tidak mampu baca tulis, 20\% berpendidikan SLTP dan hanya 16\% berpendidikan SLTA. Hal ini menghambat proses adopsi pengetahuan dan teknologi yang disuluhkan, 2)Tidak tersedianya sarana listrik yang memadai di lokasi kegiatan, hal ini menghambat/membatasi tim penyuluh untuk menggunakan peralatan pendukung seperti OHP dan LCD, 3)Kesempatan yang dimiliki tiap petani/peternak untuk mengikuti kegiatan ini tidak sama dan terbatas. Karena itu, waktu dan durasi pelaksanaan kegiatan ini menjadi sangat terbatas dan tidak optimum karena terpaksa mesti disesuaikan dengan keterbatasan kesempatan tersebut, 4)Masyarakat pada umumnya di lokasi kegiatan ini tampak telah terkondisi dengan proyekproyek pemberian bantuan sosial (bantuan material), sehingga kehadiran Tim Pengabdian kepada Masyarakat di desa diasosiasikan dengan tim dari proyek sejenis yang datang membawa atau menjanjikan bantuan material.

\section{Kesimpulan}

Berdasarkan hasil evaluasi terhadap pencapaian tujuan kegiatan yang dilaksanakan dalam pengabdian kepada masyarakat ini dapat disimpulkan, bahwa semua peternak dari kedua kelompok peternak sasaran telah memahami dengan baik materi Ipteks yang disuluhkan oleh tim penyuluh dan dipandang telah mampu mengembangkan usaha produksi kambing bibit dan bakalan dengan penerapan Teknik Reproduksi Terkontrol. Adapun pencapaian manfaat kegiatan yang dievaluasi dengan pengukuran langsung terhadap performa perbibitan yang meliputi parameter-parameter reproduktif maupun produktif kambing demplot menunjukkan, bahwa penerapan Teknik Reproduksi Terkontrol sangat bermanfaat 
dalam mengatasi rendahnya produktivitas sebagai akibat rendahnya efisiensi reproduksi ternak kambing perbibitan yang dibudidayakan.

\section{Ucapan Terima Kasih}

Secara khusus, Tim Penyuluh menyampaikan terimakasih dan penghargaan kepada Direktur DP2M Dikti dan Ketua LPPM Universitas Mataram atas persetujuan pelaksanaan program pengabdian kepada masyarakat ini, juga terimakasih kepada Direktur Pusat Studi Pembangunan Nusa Tenggara Barat (PSP-NTB) atas kerjasama dalam pembinaan kelompokkelompok peternak sasaran melalui kegiatan ini serta atas dukungan fasilitas dan penyediaan data/informasi yang sangat mencukupi selama kegiatan berlangsung.

\section{Daftar Pustaka}

Blakely, J. dan D.H. Bade, 1991. The Science of Animal Husbandry. $4^{\text {th }}$ Ed. Printic-Hall Inc. New Jersey

Devendra, C. dan M. Burns, 1994. Produksi Kambing di Daerah Tropis. Penerbit ITB, Bandung

Kaunang, D., S. Suyadi, dan S. Wahjuningsih, 2013. Analisis Litter Size, Bobot Lahir, dan Bobot Sapih Hasil Perkawinan Alami dan Inseminasi Buatan Kambing Boer dan Peranakan Etawa (PE). J. Ilmu-Ilmu Peternakan 23(3):41-46

Nasich, M., 2011. Produktivitas Kambing Hasil Persilangan antara Pejantan Boer dengan Induk Lokal (PE) Periode Pra Sapih. J. Ternak Tropika, 12(1):56-62

Nurgiatiningsih, V.M.A., 2016. Evaluasi Genetik Kambing Boer Berdasarkan Performan Hasil Persilangannya dengan Kambing Lokal. J. Ternak Tropika, 17(1):82-88

Pribadi, L.W. dan R. Rodiah, 2011. Promosi Kinerja Kambing PE sebagai Kambing Potong Unggul dengan Introduksi Genetik Kambing Boer. ORYZA, 10(2):11-21

Wodzika-Tomaszweska, M., I.M. Mastika, A. Jayanegara, S. Gardiner, dan T.R. Wiradarya, 1993. Produksi Kambing dan Domba di Indonesia. Sebelas Maret Univ. Press. Surakarta
Zaenuri, L.A., Lukman HY, dan I W.L. Sumadiasa, 2008. Kinerja Produksi dan Reproduksi Kambing Lokal yang Disilangkan dengan Kambing Boer. J. Ilmu dan Teknologi Peternakan (JITP), 4:226-223 